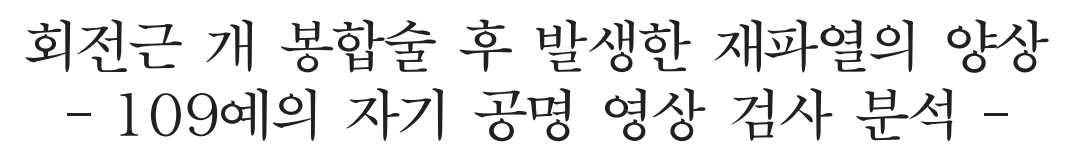

동국대학교 일산병원 정형외과, 동국대학교 경주병원 정형외과*

태석기 · 김영성* · 이호민* · 박판건

\title{
Patterns of Retear After Repair of the Rotator Cuff - MRI Analysis of 109Cases -
}

\author{
Suk-Kee Tae, M.D., Young Sung Kim, M.D.*, Ho Min Lee, M.D.*, Pan Kun Park, M.D. \\ Department of Orthopaedic Surgery, Dongguk University Ilsan Hospital, Gyeonggi-do, Korea \\ Department of Orthopaedic Surgery, Dongguk University Gyeongju Hospital, Gyeongju, Korea*
}

Purpose: This study was designed to investigate the rate of incidence, location and the clinical value of the rotator cuff retear by analyzing MRI scans, which was taken after an arthroscopic rotator cuff repair.

Materials and Methods: This study included a total of 109 patients, who underwent a shoulder MRI scan after an average of 10.6 months later from the arthroscopic rotator cuff repair. We only defined the 'retear' when the Sugaya type IV and V was observed in the sagittal section of the MRI. The location of the retear was divided into the medial and lateral areas by the site, which was $1 \mathrm{~cm}$ medial to the anchor insertion.

We investigated the incidence rate and the location of the retear, in terms of the age, sex, initial tear size and the suture method. Also, we compared the functional score of the retear group and the non-retear group, after an average of 13.9 months follow-up.

Results: There were 38 of the 109 patients that showed the rotator cuff retear. Of these patients, 25 were male patients, and 13 were female patients. Of the 38 patients with the rotator cuff retear, 21 patients were included in the $<3 \mathrm{~cm}$ retear group, and 17 were included in the $\geqq 3 \mathrm{~cm}$ retear group. At the end of the follow up period, all 109 patients showed a statistical significant improvement in the shoulder functional score.

Conclusion: According to the follow up of the MRI scan, which was taken after the rotator cuff repair, the retear rate reached $34.9 \%$, and there were no significant differences on the age and the suture method. More rotator cuff retear occurred in male patients, and the initial tear size was positively correlated with the incidence rate of the rotator cuff retear. Also, the retear was more frequently observed at the medial side. That is because when the suture was performed, excessive tension was loaded on the medial side of the suture site.

Key Words: Rotator cuff retear, Arthroscopic rotator cuff repair, Shoulder MRI

\footnotetext{
※통신저자: 이 호 민

경상북도 경주시 석장동 1090-1

동국대학교 의과대학 정형외과학교실
}

Tel: 054) 770-8221, Fax:054) 770-8378, E-mail: shoulder2011@dongguk.ac.kr

접수일: 2012년 4월 27일, 1차 심사완료일: 2012년 5월 9일, 2차 심사완료일: 2012년 5월 24일, 게재 확정일: 2012년 6월 5일 


\section{서 론}

회전근 개 봉합술 후 재파열은 흔히 발생하며 ${ }^{1-8)}$ 파열 의 크기, 파열 건의 질 등에 의하여 영향받는 것으로 알려져 있다. ${ }^{1-3.8-10)}$ 관찰된 회전근 개의 재파열율은 $13 \%{ }^{11}$ 에서 $94 \%^{11}$ 까지 다양하게 보고되어 있다. 재파열 의 진단에는 관절조영술, 초음파 및 자기 공명 영상 (magnetic resonance imaging; MRI) 등이 사용되 며 이 중 자기 공명 영상 검사가 회전근 개의 상태를 아는데 가장 우수하다. ${ }^{12}$

2005년 12월부터 현재까지 300예가 넘는 회전근 개 파열 환자들이 본원에서 관절경적 회전근 개 봉합술을 받고 대부분의 환자에서 임상적 호전을 보였다. 본원에 서는 회전근 개 봉합 후 골-건 치유 및 건의 연속성 확 인을 위해 추적 자기 공명 영상 검사를 권유하였으며, 임상적인 호전에도 불구하고 추적 자기 공명 영상 검사 에서 생각보다 많은 재파열이 있음을 확인하였다. 많은 국내 및 국외 논문에서 추적 자기 공명 영상 검사를 통 해 회전근 개 재파열에 대한 분석을 시행하였지만 ${ }^{78.12 .13)}$ 재파열 발생의 원인인자로 생각되는 요인은 논문마다 차이가 있었다. 이에 본원에서 관절경적 회전근 개 봉 합술을 받고 시행한 추적 자기 공명 영상 검사를 후향 적으로 분석하여 재파열 발생의 원인인자 및 재파열과 임상적 결과 사이의 연관성을 찾기로 하였다.

본 연구의 목적은 회전근 개 봉합술 후 최단 6 개월 이후에 시행한 자기 공명 영상 검사 소견을 분석하여 재파열의 빈도와 발생 위치, 봉합술기에 따른 재파열 양상의 차이 유무, 재파열의 발생에 영향을 미치는 인 자 및 재파열이 임상적 결과에 미치는 영향을 알아보고 자 하였다.

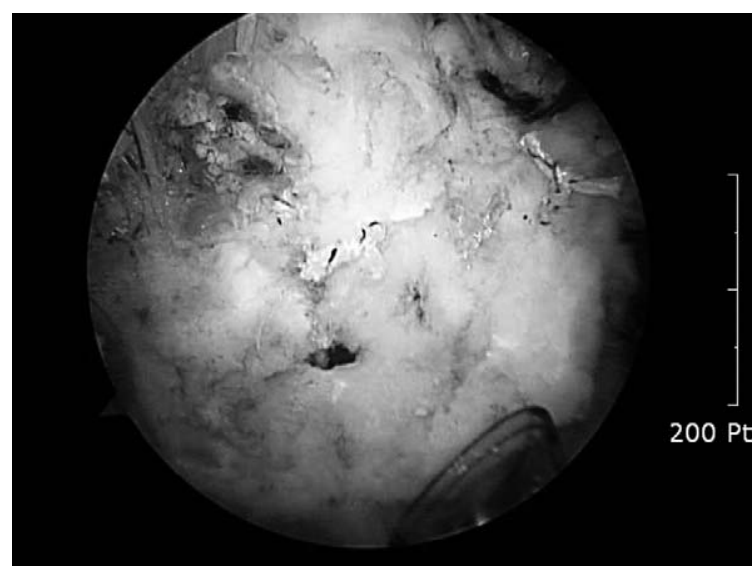

Fig. 1. Arthroscopic image from lateral portal shows repaired rotator cuff with single row technique.

\section{연구 대상 및 방법}

\section{1. 연구 대상}

2005년 12월부터 2011년3월까지 관절경적 회전근 개 봉합술을 시행한 323 예 중 추적 관찰이 소실되거나 추 적 자기 공명 영상 검사를 거부한 214예를 제외하고, 추적 자기 공명 영상 검사를 시행한 109 예를 대상으로 후향적 연구를 하였다. 환자의 평균연령은 57 세 (범위 32 77), 남자 50예, 여자 59예였다. 우세수측 견관절 에 이환된 경우가 89예 (81.7\%)였다. 35예 (32.1\%) 에서 거시적 외상 (낙상 등의 통증을 유발한 확실한 외 상력)이 있었으며 13예 (11.9\%)는 직업과 연관된 누적 손상 (이환된 어깨에 많은 부하가 가해지는 육체 노동) 에 의한 것으로 판단되었다. 유병기간은 평균 13.2 개월 (범위 10 일 20년)이고 평균 추시기간은 13.9 개월 (범 위 6 44개월)이었다.

\section{2. 평가 방법}

수술 전 모든 환자에서 자기 공명 영상 검사를 시행 하였으며 UCLA (University of California at Los Angeles) $\mathrm{score}^{14)}$ 와 Constant score ${ }^{15)}$ 를 측정하였다. 봉합술 후 평균 10.6 개월 (범위 6 38개월)에 자기 공 명 영상 검사를 시행하였으며 최종 추시점에 UCLA및 Constant score를 측정하여 수술 전의 측정치와 비교 하였다.

\section{3. 수술방법 및 소견}

수술은 관절경적 술기에 의하여 27 예는 일열 봉합술 (Fig. 1)을 82예는 이열 봉합술 (6예) 혹은 교량형 봉

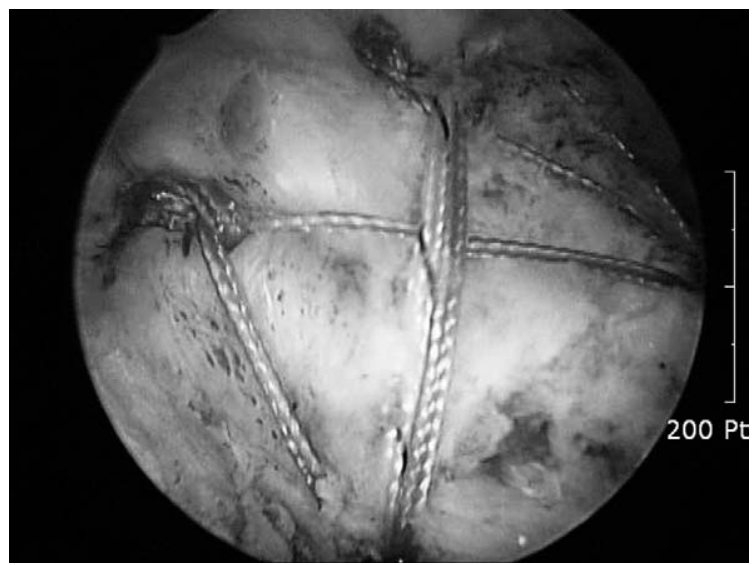

Fig. 2. Arthroscopic image from lateral portal shows repaired rotator cuff with double row technique. 
합술 (suture bridge repair, 76예) (Fig. 2)이 시행 되었으며, 이 중 7 예 $(6.4 \%)$ 에서는 수술 중 판단에 의 하여 최소절개 봉합술로 전환되었다. 86 예 $(78.9 \%)$ 에 서 견봉 성형술을 시행하였다.

회전근 개 파열의 크기는 파열 건의 변연부에 대한 최소한의 절제술 후 전후 길이와 최대 퇴축 $\left(\mathrm{maxi}^{-}\right.$ mum retraction)을 눈금이 있는 probe를 이용하여 측정하였다. 파열의 크기 (전후 길이)는 평균 $2.2 \mathrm{~cm}$ (범위 $1 \sim 6 \mathrm{~cm}$ ), 최대 퇴축은 평균 $1.7 \mathrm{~cm}$ (범위 $0.5 \sim 4 \mathrm{~cm}$ )이었다. 파열의 모양은 반달형 모양 ( $\mathrm{cres}^{-}$

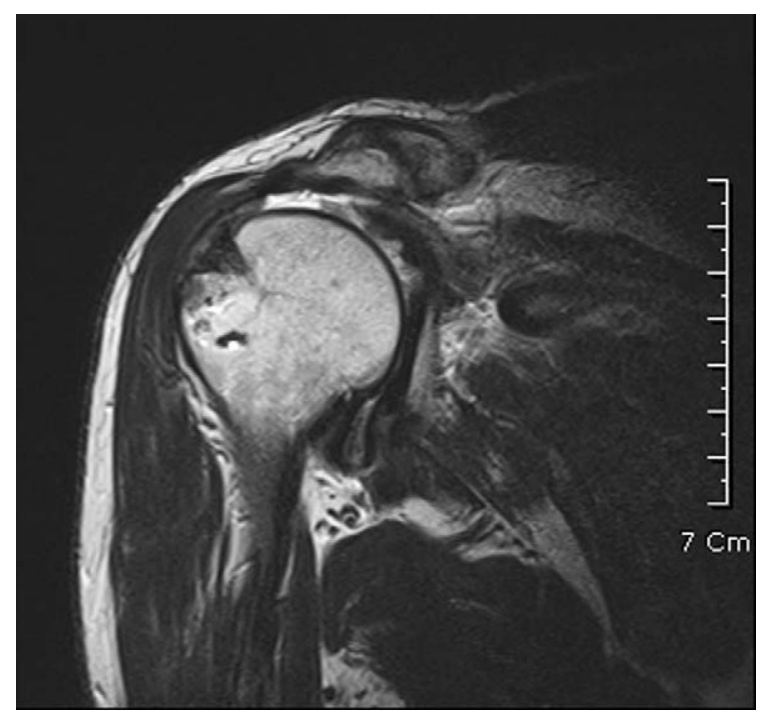

Fig. 3. Postoperative MRI at final follow-up shows discontinuity in supraspinatus tendon on top of the humeral head.

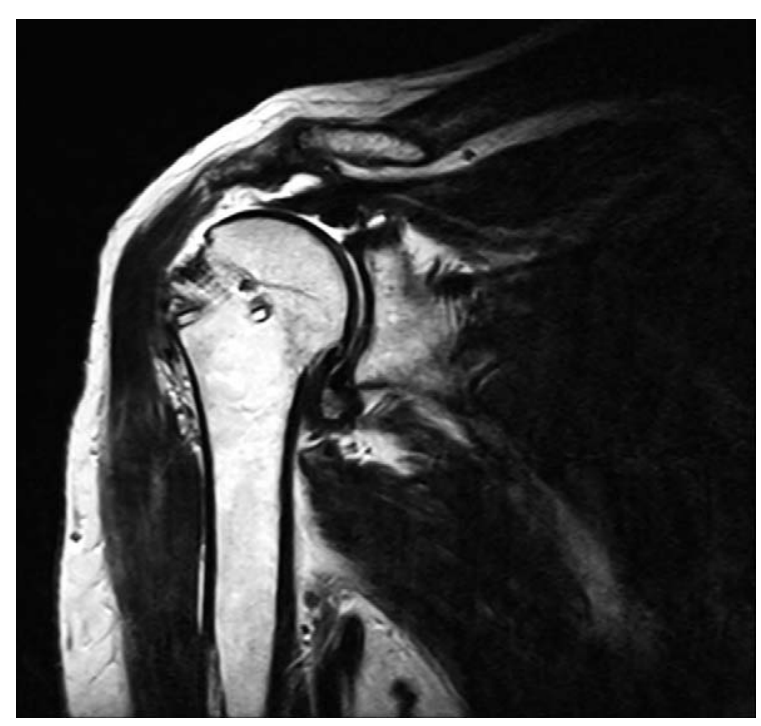

Fig. 4. Postoperative MRI at final follow-up shows discontinuity in supraspinatus tendon from anchor insertion site to top of the humeral head. cent shape) 60예 (55.0\%), L자 혹은 역L자 모양 29예 (26.6\%), U자 모양 20예 (18.3\%)였다. L 혹은 U자 모양의 파열에서는 건-건 봉합 (tendon to tendon suture)을 먼저 시행한 후 건-골 봉합 (tendon to bone suture)을 시행하였다.

파열된 건의 질은 수술자의 주관적인 기준으로 우수, 양호, 불량 세 단계로 구분하여 판단, 기록하였다. 관 절경하에서 탐침자를 이용하여 파열건의 두께를 측정하 여 $10 \mathrm{~mm}$ 이상은 우수, $5 \sim 10 \mathrm{~mm}$ 사이는 양호, 5 $\mathrm{mm}$ 미만은 불량으로 판단하였으며, 두께가 $5 \mathrm{~mm}$ 이 상인 경우에도 grasper를 사용하여 파열건을 잡아당겼 을 때 쉽게 뜯어지는 소견이 관찰되면 불량으로 판단하 였다. 우수 16 예 (14.7\%), 양호 83예 $(76.1 \%)$, 불량 10 예 $(9.2 \%)$ 이었다.

\section{4. 자기 공명 영상 검사를 이용한 결과의 평가}

건의 상태 및 재파열의 발생에 대한 평가에는 Sugaya의 기준 ${ }^{10)}$ 을 사용하였다. Sugaya I형은 충분한 건 의 두께가 유지되며 균질성 신호강도를 보이는 경우, II 형은 충분한 건의 두께가 유지되나 부분적 고신호 강도 가 보이는 경우, III형은 건의 불연속성은 없으나 얇아 진 경우, IV형은 경도의 건 불연속성이 보이는 경우, $\mathrm{V}$ 형은 현저한 건 불연속성이 보이는 경우이다. 이 중 $\mathrm{IV}, \mathrm{V}$ 형을 재파열로 규정하였다. 또한 재파열의 발생 위치를 앵커 삽입 부위의 내측 $1 \mathrm{~cm}$ 지점을 기준으로 내측 및 외측으로 구분하였다 (Fig. 3-5).

재파열의 유무를 판단한 후에는 연령, 파열의 크기,

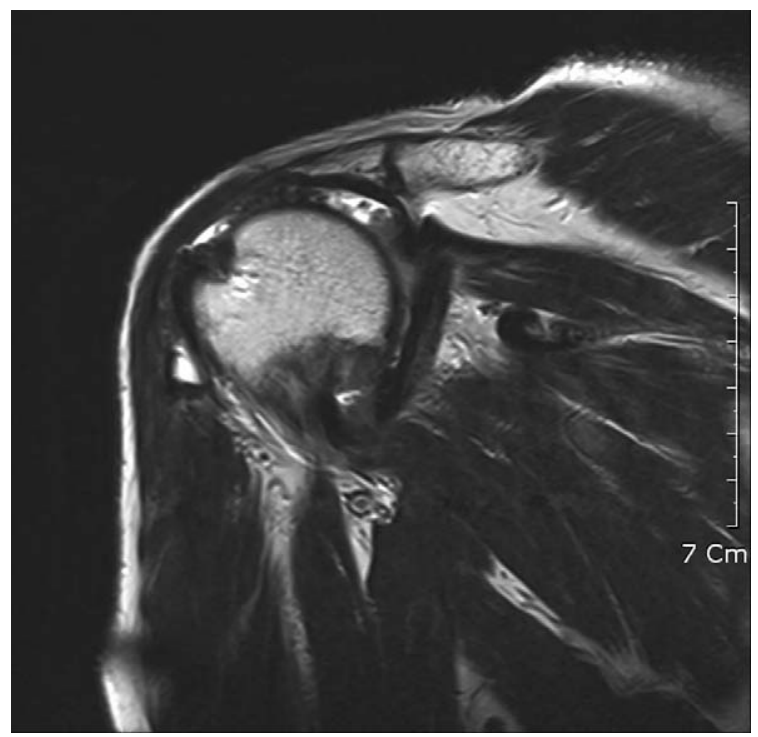

Fig. 5. Postoperative MRI at final follow-up shows discontinuity in supraspinatus tendon on anchor insertion site and top of the humeral head. 
파열 건의 질 및 봉합 방법에 따른 차이를 비교 분석하 였다.

\section{5. 통계}

통계학적 검정에는SPSS for windows Release 17.0 (SPSS. Chicago, Illinois)를 사용하였다. 성별, 나이, 통증 지속 기간, 거시적 외상, 초기 파열의 크기, 건의 질, 봉합 방법, 파열의 모양 등 여러 변수와 재파 열율과의 비교는 카이 제곱 검정을 이용하였고, 다른 변수에 의한 영향을 통제하기 위해 여러 변수와 재파열
율과의 이분형 로지스틱 회귀분석을 시행하였다.

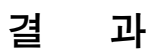

추적 자기 공명 영상 검사 결과Sugaya I형 35예 (32.1\%), II형 28예 (25.7\%), III형 8예 (7.3\%), IV 형 26예 $(23.9 \%), \mathrm{V}$ 형이 12 예 $(11.0 \%)$ 이었다. 재파 열로 정의한 $\mathrm{IV}, \mathrm{V}$ 형은 총 109 예 중 38 예 (34.9\%)에 서 발생하였다 (Table 1).

나이에 따른 비교에서 59세 이하 군과 60세 이상 군 의 재파열 비율은 의미있는 차이가 없었다 $(p>0.05)$

Table 1. Results according to sugaya's classification

\begin{tabular}{lcc}
\hline \hline Sugaya type & Number & Retear \\
\hline I (Sufficient thickness with homogenous low intensity) & 35 & No(n=71) 65.10\% \\
II (Sufficient thickness with partial high intensity) & 28 & Yes(n=38) $34.90 \%$ \\
III (Insufficient thickness without discontinuity) & 8 & 26 \\
IV (Presence of a minor discontinuity) & 12 & \\
V (Presence of a major discontinuity) & & \\
\hline
\end{tabular}

Table 2. Retear rate according to age

\begin{tabular}{lcc}
\hline \hline Age & Retear rate & Retear site (medial/lateral/both) \\
\hline Lless than $59(\mathrm{n}=67)$ & 22cases $(32.8 \%)$ & $(15 / 4 / 3)$ \\
60 and over $(\mathrm{n}=42)$ & 16 cases $(38.1 \%)$ & $(12 / 3 / 1)$ \\
$p$ value & 0.575 & \\
\hline
\end{tabular}

Table 3. Retear rate according to sex

\begin{tabular}{lcc}
\hline \hline Sex & Retear rate & Retear site (medial/lateral/both) \\
\hline Male $(\mathrm{n}=50)$ & $25 \operatorname{cases}(50.0 \%)$ & $(17 / 4 / 4)$ \\
Female $(\mathrm{n}=59)$ & $13 \operatorname{cases}(22.0 \%)$ & $(10 / 3 / 0)$ \\
$p$ value & 0.002 & \\
\hline
\end{tabular}

Table 4. Retear rate according to symptom duration

\begin{tabular}{lcc}
\hline \hline Symptom duration & Retear rate & Retear site (medial/lateral/both) \\
\hline Under 1year $(\mathrm{n}=76)$ & 27 cases $(35.5 \%)$ & $(20 / 5 / 2)$ \\
lyear and over $(\mathrm{n}=33)$ & 11 cases $(33.3 \%)$ & $(7 / 2 / 2)$ \\
$p$ value & 0.825 & \\
\hline
\end{tabular}

Table 5. Retear rate according to trauma history

\begin{tabular}{lcc}
\hline \hline Trauma history & Retear rate & Retear site (medial/lateral/both) \\
\hline Yes $(\mathrm{n}=35)$ & 15 cases $(42.9 \%)$ & $(11 / 1 / 3)$ \\
No $(\mathrm{n}=74)$ & 23 cases $(31.1 \%)$ & $(16 / 6 / 1)$ \\
$p$ value & 0.228 & \\
\hline
\end{tabular}


(Table 2). 성별에 따른 비교에서 여성보다 남성에서 재파열이 잘 발생하였다 $(p<0.05)$ (Table 3$)$. 수술 전 통증 지속 기간이 1 년 미만인 군과 1 년 이상인 군과의 비교에서 수술 전 통증 지속 기간은 재파열 빈도에 영 향을 끼치지 않았다 ( $p>0.05)$ (Table 4). 초기 파열시 외상력 유무는 수술 후 재파열 여부에 의미있는 차이를 보이지 못했다 ( $p>0.05)$ (Table 5). 초기 파열의 크기
가 $3 \mathrm{~cm}$ 미만인 군과 이상인 군과의 비교에서 파열의 크기가 클수록 재파열이 잘 발생하였다 $(p<0.05)$ (Table 6). 관절경 소견에 따라 우수, 양호, 불량으로 나눈 파열 건의 질에 따른 비교에서 재파열 비율의 의 미있는 차이는 없었다 ( $p>0.05)$ (Table 7). 수술 전 통증 지속 기간이 길수록, 즉 만성 파열일수록 파열건 의 질이 나쁠 것으로 생각되어 통증 지속 기간과 파열

Table 6. Retear rate according to tear size

\begin{tabular}{lcc}
\hline \hline Tear size & Retear rate & Retear site (medial/lateral/both) \\
\hline Under $3 \mathrm{~cm}(\mathrm{n}=82)$ & 21 cases $(25.6 \%)$ & $(15 / 4 / 2)$ \\
$3 \mathrm{~cm}$ and over $(\mathrm{n}=27)$ & 17 cases $(63.0 \%)$ & $(12 / 3 / 2)$ \\
$p$ value & 0.000 & \\
\hline
\end{tabular}

Table 7. Retear rate according to tendon quality

\begin{tabular}{lcc}
\hline \hline Tendon quality & Retear rate & Retear site (medial/lateral/both) \\
\hline Good $(\mathrm{n}=16)$ & 5 cases $(31.2 \%)$ & $(4 / 1 / 0)$ \\
Fair $(\mathrm{n}=83)$ & $29 \operatorname{cases}(34.9 \%)$ & $(21 / 6 / 2)$ \\
Poor $(\mathrm{n}=10)$ & $4 \operatorname{cases}(40.0 \%)$ & $(2 / 0 / 2)$ \\
$p$ value & 0.943 & \\
\hline
\end{tabular}

Table 8. Retear rate according to repair method

\begin{tabular}{lcc}
\hline \hline Repair method & Retear rate & Retear site (medial/lateral/both) \\
\hline Single layer $(\mathrm{n}=27)$ & 7 cases $(25.9 \%)$ & $(5 / 1 / 1)$ \\
Double layer $(\mathrm{n}=82)$ & 31 cases $(37.8 \%)$ & $(22 / 6 / 3)$ \\
$p$ value & 0.261 & \\
\hline
\end{tabular}

Table 9. Retear rate according to tear shape

\begin{tabular}{lcc}
\hline \hline Repair method & Retear rate & Retear site (medial/lateral/both) \\
\hline Crescent shape $(\mathrm{n}=60)$ & 20cases $(33.3 \%)$ & $(13 / 6 / 1)$ \\
U-shape $(\mathrm{n}=15)$ & 7 cases $(46.6 \%)$ & $(6 / 0 / 1)$ \\
L-shape $(\mathrm{n}=14)$ & $5 \operatorname{cases}(35.7 \%)$ & $(4 / 1 / 0)$ \\
Reverse L-shape $(\mathrm{n}=20)$ & $6 \operatorname{cases}(30.0 \%)$ & $(4 / 0 / 2)$ \\
$p$ value & 0.925 & \\
\hline
\end{tabular}

Table 10. Retear rate according to multiple variables (Chi-square test)

\begin{tabular}{lcc}
\hline \hline Multiple variables & Retear rate & P value \\
\hline Age $(<60 / \geq 60)$ & $32.8 \% / 38.1 \%$ & 0.575 \\
Sex $(\mathrm{M} / \mathrm{F})$ & $50.0 \% / 22.0 \%$ & 0.002 \\
Symptom duration $(<1 \mathrm{yr} / \geq 1 \mathrm{yr})$ & $35.5 \% / 33.3 \%$ & 0.825 \\
Trauma history $(\mathrm{yes} / \mathrm{no})$ & $42.9 \% / 31.1 \%$ & 0.228 \\
Tear size $(<3 \mathrm{~cm} / \geq 3 \mathrm{~cm})$ & $25.6 \% / 63.0 \%$ & 0.000 \\
Tendon quality $(\mathrm{good} /$ fair/poor) & $31.2 \% / 34.9 \% / 40.0 \%$ & 0.943 \\
Repair methods (single/double) & $25.9 \% / 37.8 \%$ & 0.261 \\
Tear shape (crescent/U/L/reverse L) & $33.3 \% / 46.6 \% / 35.7 \% / 30.0 \%$ & 0.925 \\
\hline
\end{tabular}


Table 11. Relation between multiple variables and retear (binary logistic regression analysis)

\begin{tabular}{lc}
\hline \hline Multiple variables & $p$ value \\
\hline Age $(<60 / \geq 60)$ & 0.972 \\
Sex $(\mathrm{M} / \mathrm{F})$ & 0.008 \\
Symptom duration $(<1 \mathrm{yr} / \geq 1 \mathrm{yr})$ & 0.397 \\
Trauma history $(\mathrm{yes} / \mathrm{no})$ & 0.736 \\
Tear size $(<3 \mathrm{~cm} / \geq 3 \mathrm{~cm})$ & 0.004 \\
Tendon quality $(\mathrm{good} / \mathrm{fair} /$ poor $)$ & 0.968 \\
Repair methods $($ single/double) & 0.756 \\
Tear shape $($ crescent/U/L/reverse L) & 0.642 \\
\hline
\end{tabular}

건의 질과의 연관성을 분석하였으나 $p$-value 0.149 로 통계적으로 의미있는 연관성은 없었다. 일열 봉합을 시 행한 군과 이열 봉합을 시행한 군과의 비교에서 봉합 방법에 따른 재파열 비율은 의미있는 차이가 없었다 ( $p>0.05)$ (Table 8). 파열의 모양은 crescent shape, U-shape, L-shape, reverse L-shape의 4 가지 모양 이 관찰되었으며, 파열의 모양에 따른 재파열 비율은 의미있는 차이가 없었다 ( $p>0.05)$ (Table 9$)$.

결과적으로 나이, 수술 전 통증 지속 기간, 외상력, 파열건의 질, 봉합 방법의 차이는 재파열 발생률에 영 향을 끼치지 않았고, 성별 및 초기 파열의 크기 차이는 재파열 발생률에 영향이 있었다 (Table 10).

다른 변수로 인한 영향을 통제하기 위해 다시 성별, 나이, 통증 지속 기간, 거시적 외상, 초기 파열의 크기, 건의 질, 봉합 방법, 파열의 모양과 재파열율과의 이분 형 로지스틱 회귀분석을 시행하였으며, 다른 변수를 통 제하고 나서도 결과에 큰 차이는 없었다 (Table 11).

최종 추시점에서의 견관절 기능점수는 재파열 군에서 UCLA score는 평균 17.4에서 30.0으로, Constant score는 평균 44.7에서 71.9로 증가하였다. 재파열이 발생하지 않은 군에서의 UCLA score는 평균 16.8 에 서 30.9로, Constant score는 평균 46.6에서 74.9로 증가하여 양 군 공히 견관절 기능점수는 상당한 호전을 보였다 $(p<0.05)$. 그러나, 호전의 정도에는 양 군간에 통계적으로 유의한 차이를 보이지 않았다 $(p>0.05)$.

\section{〈합병증〉}

3예에서 상완골 대결절의 골질 불량으로 인한 앵커의 불충분한 고정 또는 pull out으로 골 시멘트를 이용한 보강을 하였다. 2예에서는 앵커 삽입과정 중 발생한 대 결절의 골절에 대하여 나사못 고정을 시행하였다.

수술 중 견인으로 인하여 3예에서 일시적인 손 저림 을 보여 상완신경총 견인 증상이 있었으나 모두 3 주 내에 호전되었다.

\section{고 찰}

회전근 개의 재파열은 주로 관절 조영술, 초음파 등 으로 진단되었으나 최근에는 자기 공명 영상 검사가 흔 히 사용된다. ${ }^{7.8 .19 .20)}$ 자기 공명 영상 검사는 회전근 개 전층 파열의 진단에 민감도와 특이도가 초음파, 관절 조영술에 비해 훨씬 높다. ${ }^{21-24)}$ 본 연구에서는 재파열의 진단에 자기 공명 영상 검사를 사용하였으며, 따라서 초음파 검사를 이용한 추적검사에 의한 연구에 비하여 진단의 정확도가 높았을 것으로 보인다.

양을 이용한 실험적 회전근 개 봉합술에서 회전근 개 는 복원 후 3 개월에 온전한 건의 $52 \%, 6$ 개월에 $82 \%$ 의 강도를 보이는 것으로 보고되었다. ${ }^{25)}$ 따라서 6 개월 이후에 시행한 자기 공명 영상 검사로 복원된 회전근 개의 상태를 파악하는 것은 의미 있을 것으로 보인다.

재발성 회전근 개 파열의 진단에서 자기 공명 영상 검사가 높은 정확성을 보이기는 하나 수술 후 연부조직 신호 강도의 변화를 파열로 판정함으로써 과잉 진단될 수 있는 문제점이 있다. ${ }^{26)}$ 본 연구에서는 복원 부위에 건의 전층에 걸친 간격(gap)이 확실히 있는 경우에만 재파열로 진단하여 과잉 진단을 피하고자 하였다. 그러 나 재파열이 없는 것으로 판정한 경우에서 일부에서는 재파열이 존재할 가능성을 완전히 부정하지는 못할 것 으로 보인다.

Thomazeau 등은 회전근 개 봉합술 후 자기 공명 영상 검사를 시행하여 $73 \%$ 에서 회전근 개가 유지된 것 으로 보고하였다. Gerber 등흔 광범위 회전근 개 파 열의 봉합술을 시행한 29 명의 환자에서 자기 공명 영상 검사로 경과 관찰한 결과 $66 \%$ 에서 회전근 개가 유지된 것으로 보고하였으며, 이러한 군에서 회전근 개의 재파 열이 있는 군보다 좋은 결과를 보인다고 하였다. Chun 등 $^{13)}$ 은 회전근 개 파열에 대한 봉합술 후 재파열의 발생 비율은 중파열에서 $9 \%$, 대파열에서 $33 \%$, 광범위 파열 에서는 $61 \%$ 로 파열의 크기가 클수록 재파열의 가능성 이 높다고 보고하였다.

본 연구에서는 회전근 개 봉합술 후 재파열은 109 예 중 38예로 $34.9 \%$ 에서 발생하였으며, 그 발생률이 3 $\mathrm{cm}$ 가 넘는 파열에서는 $63.0 \%, 3 \mathrm{~cm}$ 이하의 파열에서 는 $25.6 \%$ 로 파열이 클수록 재파열의 발생 가능성이 높 음을 알 수 있다. 남성에서 발생한 재파열 비율이 $50.0 \%$, 여성에서 발생한 재파열이 $22.0 \%$ 로 남성에서 재파열 비율이 높았는데 이는 일반적으로 남성이 여성 보다 통증을 느끼는 정도가 덜하고, 수술 후 운동 교육 순응도가 떨어져 과운동을 시행한 경우가 많기 때문으 로 보인다. 회전근개 봉합술 후 5 일째 $\mathrm{VAS}$ 점수가 남 자 군에서 유의하게 낮았다는 보고도 있다. ${ }^{27)}$ 또한 재파 열은 주로 내측에서 발생하였다. 수술자는 봉합술을 시 
행할 때 건의 퇴행성 변화에 따른 고정 약화를 우려하 여 건의 많은 부분을 뼈에 고정하기 위해서 근-건 경계 부위보다 내측으로 봉합사를 통과시켰는데, 이로 인해 대결절과 건 사이의 골-건 치유는 대부분 잘 진행되었 으나 근-건 경계부위에 과도한 긴장이 발생하여 내측 재파열이 된 경우가 많았던 것으로 생각된다.

다만 재파열의 유무가 임상적 결과에 영향을 준다는 보고 $^{2-4.8)}$ 와는 달리 본 연구의 결과는 재파열 군과 비 재 파열군의 임상적 결과에서 의미 있는 차이가 없었다. 또한 파열건의 질에 따라 재파열율이 높아질 것으로 예 상되었는데 본 연구에서는 우수, 양호, 불량 세 군의 재파열율의 의미있는 차이가 없었다. 이는 아마도 우수 16 예, 불량 10 예로 두 군의 모집단의 수가 작아 통계적 으로 유의한 차이를 나타내지 못한 것으로 보인다. 추 후 더 많은 결과가 모였을 때 다시 비교해 볼 필요성이 있다. Chun 등 ${ }^{13)}$ 은 수술 전 증상 지속 기간이 길수록 재파열율이 높았다고 하였으며, Gerber 등흐는 오히려 수술 전 증상 지속 기간이 짧을수록 재파열율이 높았다 고 하였다. 본 연구에서는 수술 전 증상 지속 기간이 1 년 미만인 군과 1 년 이상인 군의 재파열율 비교에서 의 미있는 차이를 찾을 수 없었다. Gazielly 등른 나이가 많을수록 관절경적 회전근개 봉합술 후의 재파열율이 높 았다고 보고하였는데 본 연구에서는 60 세 미만인 군과 60 세 이상인 군의 재파열율이 의미있는 차이가 없었다.

본 연구는 후향적 연구이며, 일열 봉합 및 이열 봉합 을 시행한 환자군 모두를 포함하여 수술 방법에 일관성 이 없으며, 추적 자기 공명 영상 검사 시행 시점 또한 일정하지 않았다는 제한이 있다. 또한 수술을 시행한 환자의 일부에서만 추적 자기 공명 영상 검사를 시행하 였으므로 본 연구에서 얻은 수치가 재파열의 정확한 발 생빈도라 하기 어려울 것으로 보인다. 수술 후 정확한 이유를 알 수는 없으나 추시가 되지 않는 환자들이 있 었으며, 추시가 되더라도 일부 환자는 잔류 증상이 경 미하여 자기 공명 영상 검사에 응하지 않는 경우도 있 었다. 추적관찰이 되지 않았던 환자 군에서는 잔류 증 상이 없는 경우가 많았을 것으로 보이며, 검사에 응하 지 않은 환자들에서도 증상이 경미한 경우가 많았던 것 을 고려해 보면 실제 파열의 빈도는 얻은 수치보다 낮 을 가능성이 높을 것으로 판단된다.

\section{결 론}

회전근 개 봉합술 후 추적 자기 공명 영상 검사 상 $34.9 \%$ 에서 재파열이 발생하였으며 환자의 나이, 복원 방법에 따른 발생률의 차이는 없었으나 남성 및 파열크 기가 큰 경우 재파열의 가능성이 높았다. 재파열은 주 로 내측에서 발생하는 것을 관찰할 수 있었는데 이는
봉합시 과도한 긴장이 봉합부의 내측에 부하되기 때문 인 것으로 보인다.

\section{REFERENCES}

1) Galatz LM, Ball CM, Teefey SA, Middleton WD, Yamaguchi K. The outcome and repair integrity of completely arthroscopically repaired large and massive rotator cuff tears. J Bone Joint Surg Am. 2004;86:219-24.

2) Gazielly DF, Gleyze P, Montagnon C. Functional and anatomical results after rotator cuff repair. Clin Orthop Relat Res. 1994;304:43-53.

3) Gerber C, Fuchs B, Hodler J. The results of repair of massive tears of the rotator cuff. J Bone Joint Surg Am. 2000;82:505-15.

4) Harryman DT 2nd, Mack LA, Wang KY, Jackins SE, Richardson ML, Masten FA 3rd. Repairs of the rotator cuff. Correlation of functional results with integrity of the cuff. J Bone Joint Surg Am. 1991;73:982-9.

5) Jost B, Pfirrmann CW, Gerber C. Clinical outcome after structural failure of rotator cuff repairs. $J$ Bone Joint Surg Am. 2000;82:304-14.

6) Klepps S, Bishop J, Lin J, et al. Prospective evaluation of the effect of rotator cuff integrity on the outcome of open rotator cuff repairs. Am J Sports med. 2004;32:1716-22.

7) Knudsen HB, Gelineck J, S $\phi$ jbjerg JO, Olsen BS, Johannsen HV, Sneppen O. Functional and magnetic resonance imaging evaluation after single-tendon rotator cuff reconstruction. J Shoulder Elbow Surg. 1999;8:242-6.

8) Thomazeau H, Boukobza E, Morcet N, Chaperon J, Langlais F. Prediction of rotator cuff repair results by magnetic resonance imaging. Clin Orthop Relat Res. 1997:275-83.

9) Boileau P, Brassart N, Watkinson DJ, Carles M, Hatzidakis AM, Krishnan SG. Arthroscopic repair of full-thickness tears of the supraspinatus: Does the tendon really heal? J Bone Joint Surg Am. 2005;87:122940.

10) Sugaya H, Maeda K, Matsuki K, Moriishi J. Functional and structural outcome after arthroscopic fullthickness rotator cuff repair: single-row versus duallow fixation. Arthroscopy. 2005;21:1307-16.

11) Bellumore Y, Mansat M, Assoun J. Results of the surgical repair of the rotator cuff. Radio-clinical correlation. Rev Chir Orthop Reparatrice Appar Mot. 1994;80:582-94.

12) Gusmer PB, Potter HG, Donovan WD, O'Brien SJ. $M R$ imaging of the shoulder after rotator cuff repair. AJR Am J Roentgenol. 1997; 168:559-63.

13) Chun JM, Song JS, Sohn DW. Clinical outcome and 
causative factor in patients of structural failure after rotator cuff repair. J of Korean Shoulder and Elbow Society. 2008;11:29-36.

14) Ellman H, Hanker G, Bayer M. Repair of the rotator cuff. End-result study of factors influencing reconstruction. J Bone Joint Surg Am. 1986;68:1136-44.

15) Constant CR, Murley AH. A clinical method of functional assessment of the shoulder. Clin Orthop Relat Res. 1987:160-4.

16) Bishop J, Klepps S, Lo IK, Bird J, Gladstone JN, Flatow EL. Cuff integrity after arthroscopic versus open rotator cuff repair: a prospective study. J Shoulder Elbow Surg. 2006; 15:290-9.

17) Frank JB, Elattrache NS, Dines JA, Blackburs A, Crues H, Tibone JE. Repair site integrity after arthroscopic transosseous equivalent suture-bridge rotator cuff repair. Am J Sports Med. 2008;36:1496-503.

18) Lo IK, Burkhart SS. Double-row arthroscopic rotator cuff repair: Re-establishing the footprint of the rotator cuff. Arthroscopy. 2003;19:1035-42.

19) Adler RS, Finzel KC. The complementary roles of $M R$ imaging and ultrasound of tendons. Radiol Clin North Am. 2005;43:771-807.

20) Motamedi AR, Urrea LH, Hancock RE, Hawkins RJ, Ho C. Accuracy of magnetic resonance imaging in determining the presence and size of recurrent rotator cuff tears. J Shoulder Elbow Surg. 2002;11:6-10.

21) Fotiadou AN, Vlychou M, Papadopoulos P,
Karataglis DS, Palladas P, Fezoulidis IV. Ultrasonsgraphy of symptomatic rotator cuff tears compared with MR imaging and surgery. Eur J Radiol. 2008; 68(1):174-9.

22) Hodler J, Kursunoglu-Brahme S, Snyder SJ, et al. Rotator cuff disease: assessment with MR arthrography versus standard MR imaging in 36 patients with arthroscopic confirmation. Radiology. 1992;182:4316.

23) Iannotti JP, Ciccone J, Buss DD, et al. Accuracy of office-based ultrasonography of the shoulder for the diagnosis of rotator cuff tears. J Bone Joint Surg Am. 2005;87:1305-11.

24) Magee TH, Gaenslen ES, Seitz R, Hinson GA, Wetzel LH. $M R$ imaging of the shoulder after surgery. AJR Am J Roentgenol. 1997;168:925-8.

25) Gerber C, Schneeberber AG, Perren SM, Nyffeler RW. Experimental rotator cuff repair. J Bone Joint Surg Am. 1999;81:1281-90.

26) Montamedi AR, Urrea LH, Hancock RE, Hawkins RJ, Ho C. Accuracy of magnetic resonance imaging in determining the presence and size of recurrent rotator cuff tears. J Shoulder Elbow Surg. 2002;11:6-10.

27) Cho CH. Gender-related difference in intravenous patient-controlled analgesia for postoperative pain control in rotator cuff repair. J Korean Orthop Assoc. 2010;45:31-6. 


\section{초 록}

목적: 관절경적 회전근 개 봉합술 후 시행한 자기 공명 영상 검사 소견을 분석하여 재파열의 빈도 와 발생 위치, 재파열이 임상적 결과에 미치는 영향 등을 알아보고자 하였다.

대상 및 방법: 관절경적 회전근 개 봉합술 후 평균 10.6 개월에 자기 공명 영상 검사를 시행한 109예 (평균 연령 57세, 남:여=50예:59예)를 대상으로 하였다. 관상면 자기 공명 영상 검사 상 Sugaya IV, V 형을 재파열로 규정하였다. 재파열의 위치는 앵커 삽입부위 내측 $1 \mathrm{~cm}$ 를 기준으 로 내측 및 외측으로 구분하였다. 나이, 성별, 파열의 크기 및 복원 방법에 따른 재파열의 빈도와 위치를 알아보았으며, 평균 13.9 개월에 추시 후 재파열 유무에 따른 견관절 기능점수의 차이를 조사하였다.

결과: 109 예 중 38예 (34.9\%)에서 재파열을 보였다. 남성에서 재파열은 25예 $(50.0 \%)$ 가 발생 하였으며, 여성에서 재파열은 13 예 $(22.0 \%$ )가 발생하였다. $3 \mathrm{~cm}$ 미만 크기의 파열에서는 21 예 (25.6\%)에서 재파열이 발생하였으며, $3 \mathrm{~cm}$ 를 넘는 크기의 파열에서는 17 예 $(63.0 \%)$ 에서 재파 열이 발생하였다. 재파열이 내측에서 발생한 경우는 일열봉합에서 $71.4 \%$, 이열봉합에서 $71.0 \%$ 이었다. 최종 추시점에서 재파열군과 재파열이 없는 군 모두 견관절 기능점수는 통계학적으로 유 의한 호전을 보였으며 양 군간의 호전 정도의 차이는 없었다.

결론: 회전근 개 봉합술 후 추적 자기 공명 영상 검사상 $34.9 \%$ 에서 재파열이 발생하였으며 환자 의 나이, 복원방법에 따른 발생률의 차이는 없었으나 남성 및 파열크기가 큰 경우 재파열의 가능 성이 높았다. 재파열은 주로 내측에서 발생하는 것을 관찰할 수 있었는데 이는 봉합시 과도한 긴 장이 봉합부의 내측에 부하되기 때문인 것으로 보인다.

색인 단어: 회전근 개 재파열, 관절경적 회전근 개 봉합술, 견관절 자기 공명 영상 검사 